Research Report No. 16/2010

\title{
Market Integrity and Regulatory Systemic Risk: Insight from the Market Oriented Blockholder Model
}

Aviv Pichhadze

Follow this and additional works at: http:/ / digitalcommons.osgoode.yorku.ca/clpe

\section{Recommended Citation}

Pichhadze, Aviv, "Market Integrity and Regulatory Systemic Risk: Insight from the Market Oriented Blockholder Model" (2010). Comparative Research in Law \& Political Economy. Research Paper No. 16/2010.

http://digitalcommons.osgoode.yorku.ca/clpe/84 


\section{OSGOODE}

OSCOODE HALL LAW SCHOOL YOR K U N I VERSITY

\section{OSGOODE HALL LAW SCHOOL}

Comparative Research in Law \& Political Economy

RESEARCH PAPER SERIES

Research Paper No. 16/2010

\section{MARKET INTEGRITY AND REGULATORY SYSTEMIC RISK: INSIGHT FROM THE MARKET BLOCKHOLDER MODEL}

Aviv Pichhadze

\section{Editors:}

Peer Zumbansen (Osgoode Hall Law School, Toronto, Director, Comparative Research in Law and Political Economy)

John W. Cioffi (University of California at Riverside)

Lisa Philipps (Osgoode Hall Law School, Associate Dean Research)

Nassim Nasser (Osgoode Hall Law School, Toronto, Production Editors) 


\section{Aviv Pichhadze \\ Osgoode Hall Law School, York University, Toronto, Canada Correspondence: 131 Oak Avenue, Richmond Hill, ON, L4C 6R6, Canada; Tel: \\ +1.905.597.17.70; Email: avivpichhadze@osgoode.yorku.ca \\ Aviv Pichhadze (C) 2010. All rights reserved.}

The article benefited from com-ents on previous versions by Amir Pichhadze, Fred Gorbet, and Ed Waitzer. I would like to ex-end my gratitude to Jacob A. R. ve YaZi whose support made this study possible. Any errors, missions, as well as, the opinions expressed in this paper are my own. 


\title{
MARKET INTEGRITY AND REGULATORY SYSTEMIC RISK: INSIGHT FROM THE MARKET ORIENTED BLOCKHOLDER MODEL
}

\begin{abstract}
:
I adopt a novel approach vis-à-vis systemic risk in the capital markets and securities regulation in the US in light of the recent economic crisis. I show that regulators can introduce into the regulatory framework "regulatory systemic risk" - long-term imbalances introduced into the regulatory framework via regulatory initiatives premised on a distorted understanding of market realities thereby reducing investor protection. This results mainly from failure to (i) take note of the general market trend towards the market oriented blockholder model and (ii) update the regulatory framework accordingly. The extent of the regulatory systemic risk is also discussed. From theoretical, practical and policy perspectives the analysis illustrates the need for regulators to be cognizant of long-term trends in the capital markets in the process of addressing lessons from the recent economic crisis in order to foster improved market efficiency, enhanced shareholder protection, and remove imbalances embedded in the current regulatory framework.
\end{abstract}

Key Words:

Capital Markets; Corporate Governance; Institutional Investors; Ownership; Regulation; Risk

\section{INTRODUCTION}

This article is concerned with systemic risk in the capital markets and securities regulation. Using the corporate governance arena in the American capital markets as an example, I highlight the need for regulators to be cognizant of long-term trends in the capital markets in order to minimize the possibility for the introduction of system risk by regulators into the markets or, phrased differently, systemic risk resulting from regulation (i.e., regulatory systemic risk). Such a cautionary approach is mandated in order to avoid (i) the introduction of distortions into the new financial framework contemplated by policymakers and/or (ii) the elimination of existing distortions if such new framework is to be premised on the existing one. ${ }^{1}$

Regulatory systemic risk, as contemplated in this article, results from a distortion introduced by regulation into the regulatory framework in cases where the foundation underlying regulatory initiatives is inconsistent with market realities and, as a result, such regulatory initiatives do not adequately address the needs of the subject of the regulation as in the case of a misdiagnosis of a symptom that results in the administration of inappropriate medication (though the error may not be immediately or readily visible). As such, regulatory systemic risk may result in structural imbalances, which may, in turn, translate into reduced investor protection.

\footnotetext{
${ }^{1}$ For examples of some the alternatives being considered in the US see, e.g., Establishing a Framework for Systemic Risk Regulation: Hearing Before the Committee on Banking, Housing and Urban Affairs, United States Senate (Jul. 23, 2009) (statement of Mary L. Schapiro, Chairman, Securities and Exchange Commission) available at http://www.sec.gov/news/testimony/2009/ts072309mls.htm (proposing the establishment of a macro-prudential regulator, the Systemic Risk Regulator, to supplement and complement the existing framework of regulation).
} 
To illustrate regulatory imbalance, I use the proxy rules in the US. ${ }^{2}$ These rules appear to be premised on the continued understanding that the typical American firm can be characterized as having diffused ownership and, as a consequence, shareholders in such firms require protection from incumbent managers. ${ }^{3}$ It has been argued, however, that this premise results from a misreading of the often cited study by Berle and Means, ${ }^{4}$ and, as such, both the premise and its continued echoing constitute the introduction of distortions into the corporate governance analysis and, consequently, into the regulatory framework. ${ }^{5}$

Such distortions, in turn, may result in the inadvertent creation of imbalance in the regulatory framework. I provide two examples for such imbalance. The first type of imbalance relates to the fact that the rules appear to address the needs of shareholders in large corporations (as oppose to the needs of all the shareholders, including those in small and medium sized corporations). The second type of imbalance stems from the treatment of certain category of shareholders (i.e., institutional investors).

A student of the area will be aware that these distortions, and the imbalance they may give rise to, extend beyond the proxy rules and affect other aspects of the regulatory framework. This is because corporate ownership structures within a given economy touch on a number of key governance arrangements. ${ }^{6}$ As such, corporate ownership impacts the overall regulatory framework of securities regulation. Accordingly, these distortions give rise to regulatory systemic risk if ignored and/or left unattended.

The article is structured as follows. Part II anchors the issue of regulatory systemic risk in the context of recent economic developments in the global financial market. More particularly, it draws the linkages between regulatory systemic risk and corporate governance. Part III describes the structural imbalances in the current state of American securities regulation that result from the failure by market participants (including regulators) to recognize that the trend in the US equity markets has been towards what I referred to as the Market Oriented Blockholder Model (MOBM). ${ }^{7}$ This section also provides a bird-eye-view of the MOBM and the reasons for the importance of

${ }^{2} 15$ U.S.C. § 78n. Section 14(a) provides, inter alia, that "[i]t shall be unlawful for any person ... to solicit or to permit the use of his name to solicit any proxy or consent or authorization in respect of any security (other than an exempt security) ...."

${ }^{3}$ Mark A. Sargent \& Dennis R. Honabach, Proxy Rules Handbook § 1:1 Proxy Regulation and the Corporation Governance Debate (October 2009) (Westlaw). For a recent example of this assertion, see, e.g., Facilitating Shareholder Director Nominations, 17 CFR Parts 200, 232, 240, 249 and 274 [Release Nos. 33-904660089; IC-28765; File No. S7-10-09], at 29025 [hereinafter "Proposal"] (the idea behind the Proposal is to make boards of directors accountable to shareholder interests. Thus, shareholders, who otherwise have the right to nominate directors at a shareholder meeting, will be able to have their nominees included in the company proxy ballot sent to all voters).

${ }^{4}$ Adolf A. Berle \& Gardiner C. Means, Modern Corporation and Private Property (1932).

${ }^{5}$ Aviv Pichhadze, The Nature of Corporate Ownership in the USA: The Trend Towards the Market Oriented Blockholder Model, 5 CMLJ 63 (2010).

${ }^{6}$ See, e.g., Lucian A. Bebchuk \& Assaf Hamdani, The Elusive Quest for Global Governance Standards, 157 U. Pa. L Rev. 1263, 1270 (2009).

${ }^{7}$ Pichhadze, supra, note 5. 
ownership patterns to the discussion of corporate governance, in general, and regulatory systemic risk in particular. Part IV provides some concluding remarks.

\section{REGULATORY SYSTEMIC RISK IN CONTEXT}

Recent events in the global financial sector have resulted in heightened public and regulatory interest in increased regulation in the financial markets and the extension of regulation into new areas. ${ }^{8}$ While much of the discourse on the issue relates to financial intermediaries (e.g., investment houses) and certain financial products (e.g., over-the-counter derivatives) that can introduce or enhance systemic risk in the capital markets, other, less frequently discussed, areas can induce imbalance in the regulatory framework (e.g., regulations that do not mirror neatly the realities in the marketplace). The latter type of imbalance (and its resulting risk) is the concern of this article.

To appreciate this observation we must first establish what I mean by systemic risk and imbalance. Schapiro distinguished between two types of systemic risk: (i) near-term systemic risk and (ii) long-term systemic risk. Near-term systemic risk results from seizures or cascading failures. This type of systemic risk relates to the stability of the financial markets and, in its operational aspects, can be described as a condition that can lead to the breakdown in the provision of financial services due to factors that result in the seizure of the markets. Examples of factors that may result in this type of systemic risk include catastrophic failure of major players (in the banking sector) and the inability to process or validate trades (in the securities industry). ${ }^{9}$ Longer-term risk results from the unintentional bias towards larger institutions at the expense of smaller participants. Consequently, Schapiro cautioned, "[w]e must be very careful that our efforts to protect the system from near-term systemic seizures do not inadvertently result in a long-term systemic imbalance.”10 To do this successfully, we need to, inter alia, "address structural imbalances that facilitate the development of systemic risk by closing gaps in regulations ...”11

To meet such challenges adequately, we must first observe the structural regulatory imbalances and gaps currently embedded in the system. That is, we need to treat the regulatory framework as a system - an aggregate of policies and regulations forming a connected or complex whole. Viewed in this way, systemic risk, in the context of the securities regulatory framework, is a problem that pertains to the system (i.e., the regulatory framework). This can arise, as noted earlier, in cases where policy initiatives and regulations do not align with market realities thereby creating regulatory gaps, which over time become embedded in the regulatory framework and their influence extends to other areas of the framework. Thus, giving rise to imbalances (of a long-term nature) that are systemic to the regulatory framework. That is, imbalances that give rise to regulatory systemic risk.

\footnotetext{
${ }^{8}$ See, e.g., Schapiro, supra, note 1 (for a US example); and Expert Panel on Securities Regulation, Creating an Advantage in Global Capital Markets: Final Report and Recommendations (2009), 11, available at http://expertpanel.ca/eng/reports/index.html (for a Canadian example).

${ }^{9}$ But see, Steven L. Schwarcz, Systemic Risk, 97 Geo. L.J. 193 (2008) (pointing to the vagueness and inconsistency in the usage of the term "systemic risk" in the literature).

${ }^{10}$ Schapiro, supra, note 1.

${ }^{11}$ Id.
} 
In order to simplify the analysis, the discussion will adopt a narrower view to the issue by limiting the examination to corporate governance and public corporate ownership patterns. In this context, it has been noted that there is a causal link between corporate governance and systemic risk. While recent event in the global financial markets may not have been triggered by bad corporate governance practices, "some of the negative effects could probably have been mitigated, or even perhaps avoided, by better corporate governance." 12 This is because "[g]ood corporate governance underpins the success and integrity of corporations, institutions and markets."13

It is in the context of corporate governance, however, that we see examples of the seeds of structural imbalance in the overall regulatory framework of the securities markets. These imbalances are capable of translating themselves into regulatory systemic risk if ignored by regulators. These imbalances result from the introduction, and carrying forward, of distortions into the regulatory framework. The distortions relevant to the discussion in this article relate to our observations vis-àvis the ownership patterns in the US.

More particularly, the article is concerned with the neglect to notice that the pattern in the US equity markets vis-à-vis ownership has been experiencing a change in the demographics of equity ownership (from individual to institutional ownership) that facilitated the trend towards the MOBM over the course of the $20^{\text {th }}$ century. While I discuss the distortions giving rise to regulatory imbalances and, thus, regulatory systemic risk in detail in the next section of this article, I would like to address the reasons for my examination of ownership structures in a discourse relating to market integrity and systemic risk.

Ownership structures affect several key governance arrangements and, as such, the regulatory framework that defines and affects them. For example, it has been observed that ownership structures affect arrangements such as "those regulating control contests, voting procedures, the allocation of power between directors and shareholders, the distribution of power among shareholders ... director independence, and corporate transactions that may divert value to insiders." ${ }^{24}$ In addition, it has been observed that ownership structure affects such matters as (i) takeovers and defensive measures adopted by firms to thwart such activity, (ii) conflict of interest rules and related party rules, and (iii) significant corporate action and disclosure rules. ${ }^{15}$

Accordingly, the observation vis-à-vis changing investor demographics in the sense noted above and the realization that the MOBM is an accurate reflection of the ownership pattern in the American equity markets has broad implications to the regulatory framework applicable to these markets. To understand these implications more fully, we need to appreciate the trend towards the MOBM.

\footnotetext{
12 Angel Gurria, Secretary-General, OECD, Opening remarks at the ICGN Annual Conference, Seoul (June 19, 2008), available at http://www.oecd.org/document/57/0,3343,en_2649_37439_40875513_1_1_1_1,00.html.

${ }^{13} I d$.

${ }^{14}$ Bebchuk \& Hamdani, supra, note 6.

${ }^{15}$ Reinier R. Kraakman et al. eds., The Anatomy of Corporate Law: A Comparative and Functional Approach (2004).
} 


\section{STRUCTURAL IMBALANCES: THE PROXY RULES EXAMPLE}

Long-term structural imbalances leading to regulatory systemic risk, as noted above, can result from the introduction of biases that favour large institutions at the expense of smaller ones. Such imbalances, however, can, as suggested, also result from regulation in cases where there exists a gap between the basic premise of the regulation and market realities. I first provide a bird's eye view of the MOBM. The discussion then turns to illustrating the two types of imbalance in the context of the proxy rules.

\section{A The Market Oriented Blockholder Model: A Prag- matic Approach}

The MOBM is a hybrid ownership structure featuring blockholder pattern of ownership that works with market mechanisms for the promotion of maintaining stability in the pattern of ownership (i.e., the maintenance of ownership equilibrium at the blockholder levels). This is a unique, and important, feature of the American capital markets given that economies characterized as displaying blockholder mode of corporate ownership are generally said to have a weak market for corporate control. ${ }^{16}$ The emergent blockholder in the US is the institutional investor.

The MOBM is created through the need of market forces to arrive at an ownership equilibrium that affords both liquidity in the capital markets and monitoring of corporate management. As such, the MOBM can be seen as a product of the efforts of market forces to splice blockholder components onto a market system. Consequently, such a synthesis of the blockholder mode of ownership with market mechanisms (such as takeovers) allowed for the transformation of what Coffee described as the tradeoffs between the effective monitoring of corporate managers and the promotion of efficient and liquid markets resulting from the choice of the two polar ownership structures (i.e., concentrated and diffused, respectively) ${ }^{17}$ into complements. $^{18}$

The MOBM is facilitated by market mechanisms that assist in the promotion of such an equilibrium and its maintenance over time. Maintenance is required because the ownership equilibrium, once achieved, does not remain in a static state but, rather, it is a dynamic process that exhibits deviations from, and restoration to, the state. In this dynamic process, market mechanisms such as corporate control transactions (including private equity) have an important role in restoring the equilibrium state when disturbances or deviations from the equilibrium state occur.

As Pound observed, in the context of leveraged buyout transactions, "[o]versight by entrepreneurial insurgent investors has been generated by two central (and related) features of U.S. capital markets: their fragmentation and their openness to innovation.”19 According to this view, when the

\footnotetext{
${ }^{16}$ Bebchuk \& Hamdani, supra, note 6.

17 John C. Coffee, Jr., The Future as History: The Prospects for Global Convergence in Corporate Governance and Its Implications, 93 Nw. U.L. Rev. 641, 648 (1999).

${ }^{18}$ Pichhadze, supra, note 5, at 83.

${ }^{19}$ John Pound, Raiders, Targets, and Politics: The History and Future of American Corporate Control, 5 J. App. Corp. Finan. 6, 8 (1992).
} 
ownership of a public firm becomes too fragmented such that (i) the firm experiences a reduction in the effective monitoring of the firm's management, and (ii) such reduced monitoring results in the introduction of inefficiencies into the firm, then (iii) market mechanisms such as takeover activity introduce into the firm improved monitoring and enhanced efficiency by, inter alia, concentrating, at least temporarily, the ownership of the firm.

Thus, advancement of the MOBM required two principal realizations by market observers. First, as industrial blockholders were diminishing from the large public corporation landscape during the early part of the $20^{\text {th }}$ century, market forces, in looking to fill the ownership gap, were reconcentrating ownership into the hands of fiduciaries that could take up the role of blockholders in these firms. Second, to achieve/maintain stability of this form of ownership, institutional investors, qua blockholders, realized that (in order to protect their investment, ensure increased returns on such investment, and ensure liquidity for such investments) they need to participate in the market for corporate control, as they have done since the 1980s.

In order to facilitate their fuller participation in this type of activity, institutional investors successfully lobbied regulators for the amendment to rules (as in the case of the proxy rules), when such rules prevented their fuller participation in the takeover arena. ${ }^{20}$ This activity was complemented by active investors who (as gap-fillers in the corporate governance vacuum created because of fragmented ownership) realized the dual role and importance of institutional investors (as both providers of capital and blockholders) for the execution of deals.

While the discussion in this article emphasizes the imbalances inherent in the regulatory framework due to the failure to appreciate the emergent ownership structure in the US, in the context of the MOBM, however, the fact that the model represents the emerging ownership pattern in the US points to an interesting observation. It can be argued that the trend towards the MOBM exemplify the market's attempt to achieve a socially optimal ownership structure, in addition to an optimal ownership structure (i.e., one that provides both market liquidity and enhanced monitoring of management).

Social optimality in the context of the corporation refers to the notion that the shareholders' representatives serve the shareholders' interest. ${ }^{21}$ One way of ensuring that this social welfare is met in the context of the corporation is through the monitoring of managers. The problem is that absent anyone owning sufficient stakes in the corporation, monitoring is left to market-mechanisms such as takeovers. $^{22}$

To meet these challenges, market forces and socio-economic realities in the US created a venue for the promotion of social optimality in the corporation. They have paved the way for the reconcentration of equity ownership into the hands of institutional investors - a group of investors that has sufficient stake in the corporation and, therefore, an interest in monitoring corporate man-

\footnotetext{
${ }^{20}$ See discussion in Part III(B)(ii) of this article. See, also, Pichhadze, supra, note 6, at 79.

${ }^{21}$ Sanford J. Grossman \& Oliver D. Hart, Takeover Bids, The Free-Rider Problem, and the Theory of the Corporation, 11 Bell J. Econ. 42 (1980).

${ }^{22} I d$.
} 
agers. By re-concentrating ownership into the hands of institutional investors, market forces have been reducing the costs associated with monitoring via voice because "[w]here a few institutions between them hold a majority or near-majority stake, they can often exercise a powerful, if informal, influence behind the scenes in the management of companies.”23

Institutional investors, as blockholders, and takeovers are also two key features in the MOBM. They promote efficiency and liquidity in the capital markets while enabling the increased monitoring of corporate managers. In addition, given that a feature of the MOBM is the presence of a blockholder (whether an institutional or not), it points to the observation that market forces, in gravitating towards the MOBM, are attempting to reduce the sub-optimality created by the diffused ownership pattern of corporate ownership. ${ }^{24}$

This optimistic view of the markets, created through the realization of the MOBM, needs, however, to be complemented by regulatory awareness - an awareness that requires regulators to take positive steps vis-à-vis the correction of imbalance or deficiencies in regulatory framework of the capital markets. These positive steps include, inter alia, a re-examination of the regulatory framework in areas impacted by the evolving demographic nature of the shareholder body in the American firm. This is because different ownership patterns create different opportunities and demands for regulation. ${ }^{25}$

B The Proxy Rules: an Example for Structural Imbala n c e

The proxy rules in the US exemplify the long-term systemic imbalance mentioned earlier. In the US, these rules are found in s. 14 of the Securities and Exchange Act of $1934 .^{26}$ It has been argued that s. 14 "derive directly from the Berle-Means description of the public corporation and the belief that managerialism represented a threat to public shareholders.",27

${ }^{23}$ Simon Deakin et al., Anglo-American Corporate Governance and the employment relationship: A Case to Answer?, 4 Socio-Economic Rev. 155, 160 (2006).

${ }^{24}$ As Bebchuk \& Zingales observed, "the incidence of IPOs ... is larger in the United States than in other advanced economies ... While this large incidence of IPOs is generally taken to be a socially optimal outcome, our results suggest the possibility that this incidence is excessive" [emphasis added] (Lucian Arye Bebchuk \& Luigi Zingales, Ownership Structures and the Decision to Go Public: Private versus Social Optimality, in Concentrate Corporate Ownership 55, 57 (Randall Morck ed., 2000)). The assumption in the Bebchuk and Zingales analysis appears to be that going public translates into the assumption of diffused ownership structure for the corporation (i.e., atomistic share ownership).

25 See, e.g., Bebchuk \& Hamdani, supra, note 7 (discussing the various implications of the two extreme forms of ownership - i.e., diffused and concentrated - to regulation); see also, Kraakman et al, supra, note 15.

${ }^{26} 15$ U.S.C. $\S 78 \mathrm{n}$. Section 14(a) provides, inter alia, that "[i]t shall be unlawful for any person ... to solicit or to permit the use of his name to solicit any proxy or consent or authorization in respect of any security (other than an exempt security) ...."

${ }^{27}$ Sargent \& Honabach, supra, note 3. 
Briefly stated, Berle and Means ${ }^{28}$ observed that, by the early 1930s, the wealth of corporate America was concentrated in the hands of that nation's largest corporations and that these corporations have experienced the separation of ownership from control. ${ }^{29}$ The Berle and Means study gave rise to two related observations. The first observation relates to the ownership pattern in large corporations. In that context, Berle and Means noted that the largest firms in the US at the time displayed an atomistic pattern of ownership. This observation about a fraction of the firms in the public markets, however, was generalized and internalized in the literature to encompass all of the firms in these markets. More importantly, the generalization became to be "the dominant corporate paradigm of $20^{\text {th }}$-century American capitalism." 30 The second observation relates to the balance of power within these corporations resulting from the diffusion of ownership. In that context, Berle and Means noted that the atomistic shareholders were under the influence of incumbent managers.

Over the years since the introduction of the proxy rules, the foundation of the proxy rules, as being based on the Berle-Means Corporation, has not changed (as in the case of the Proposal). ${ }^{31}$ The fact that the proxy rules are based on the Berle-Means Corporation introduces a systemic imbalance into the regulatory framework in two ways. One type of imbalance relates to the apparent bias in favour of shareholders of large corporations. The second type of imbalance relates to the treatment of institutional investors in both academic and regulatory circles.

\section{(i) First source for imbalance in the proxy rules: A bias towards large institutions and their shareholders}

The first source of long-term structural imbalance stems from the little attention that the majority of the firms in Berle and Means' study received in the literature on corporate governance. Berle and Means were principally concerned with large corporations. These large firms only accounted for approximately $23 \%$ of the firms in their study. The remaining firms (or approximately $77 \%$ of the listed firms in their study) displayed blockholder type of ownership pattern. ${ }^{32}$ As such, the proxy rules, being based on the Berle-Means Corporation, when created, were designed to address the needs of shareholders of the minority of firms in the US equity markets at the time (i.e., shareholders of large firms).

Such an approach to regulation introduces an imbalance (between the shareholders of large firms, on the one hand, and those of small and medium size firm, on the other). This is because "[a] shift in corporate legal structure appropriate enough for the corporate giant might be burdensome or

\footnotetext{
${ }^{28}$ Berle \& Means, supra, note 4.

${ }^{29}$ Id. at 47-68.

${ }^{30}$ Franklin R. Edwards \& Glenn Hubbard, The Growth of Institutional Stock Ownership: A Promise Unfulfilled, 13 J. Appl. Corp. Finan. 92 (2000).

${ }^{31}$ See, e.g., Proposal, supra, note 3.

32 Berle \& Means, supra, note 4, at 27. For a fuller discussion see Pichhadze, supra, note 5, at 66-68 (noting that the treatment of the observations made by Berle and Means vis-à-vis large firms as an all inclusive paradigm carries the risk of failing to appreciate the market as a whole, which, in turn, risks the introduction of a distortion into the corporate governance analysis).
} 


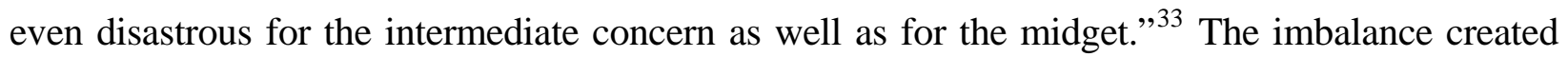
can be seen through the focal lens of regulatory attention that each type of ownership merits.

In the case of atomistic ownership, the regulatory concern is the protection of the shareholders from, for example, potential abuses by management (i.e., shareholder-manager type tension). In the case of blockholder ownership, the regulatory concern needs to address the protection of minority shareholder interests from, for example, abuse of this group by the blockholder (i.e., minority shareholder-blockholder type tension). Thus, tilting regulatory attention in favour of one type of ownership structure (in this case, 23\% of the listed firms in the Berle and Means study) may come at the expense of the other (in this case, $77 \%$ of the listed firms of the Berle and Means study). Phrased differently, by assuming that the regulated market displays a certain type of ownership structure and instituting policy initiatives based on such an assumption, regulatory gaps are created (and, hence, an imbalance is introduced into the regulatory framework) when such assumptions are based on a distorted view of the markets.

The picture becomes grimmer as we move to the present day, where the growth and size of holdings of institutional investors have altered our conception of the Berle-Means Corporation even in the case of large firms. ${ }^{34}$ Despite this, the regulatory understanding is that the diffusely owned corporation, in the Berle and Means sense, is still the proper foundation for the proxy rules (as in the case of the Proposal). This regulatory approach is supported by academic literature that holds that, although fragmented ownership is mainly characteristic of large corporation, "[t]he largest companies are very much giants among their corporate brethren. As a result, a separation between ownership and control remains an appropriate reference point ... ."35 According to this view, the size of the regulated entity should dictate regulatory approaches. This is despite the fact that even this class of corporations (i.e., large firms) has been experiencing a re-concentration of ownership into the hands of institutional investors and, consequently, this class of firms does not neatly qualify as the Berle-Means Corporation.

Stated differently, the seeds for imbalance in favour of large institutions (in this case large corporations and their shareholders) were planted in the regulatory framework and they have been carried forward to the present day despite the demographic changes in the landscape subject to the regulatory framework (referring to the institutionalization of the American capital markets).

\section{(ii) Second source of imbalance in the proxy rules: The treatment of institutional inves- tors}

A second source of structural imbalance stems from the treatment of institutional investors. These institutions in the US have grown tremendously since the early decades of the $20^{\text {th }}$ century and to-

\footnotetext{
33 Detlev F. Vagts, Reforming the 'Modern' Corporation: Perspectives from the German, 80 Harv. L. Rev. 23,32 (1966).

${ }^{34}$ See, generally, discussion in Pichhadze, supra, note 5.

${ }^{35}$ Brian R. Cheffins \& Steven A. Bank, Is Berle and Means Really a Myth? (UCLA School of Law, Law-Econ Research Paper No. 09-05; ECGI - Law Working Paper No. 121/2009, 2009), available at http://ssrn.com/abstract=1352605.
} 
day account for over $66 \%$ of equity holdings in the US. ${ }^{36}$ Since those early days, they have been viewed as agents for the dispersion of ownership. ${ }^{37}$ This is despite the fact that, during those early decades, institutional investment was restricted primarily to debt securities.

The view of institutional investors as agents for the promotion of diffused ownership has been carried forward to the present day, ${ }^{38}$ despite the fact that since the 1950 s equity ownership in the American equity markets has been gradually concentrating into the hands of institutional investors thereby institutionalizing these markets. ${ }^{39}$ Consequently, we see the emergence of a paradox in the literature on corporate governance vis-à-vis institutional investors - a paradox that may also result in a distorted regulatory treatment of this group of investors by regulators.

The paradox can be stated concisely in the following terms. On the one hand, as we have seen, institutional investors are credited for the promotion of dispersed ownership. On the other hand, however, these investors are, in reality, promoting the re-concentration of ownership into the hands of financial blockholders or fiduciaries. This paradox features prominently in the shareholder primacy literature, which asserts, inter alia, that institutional investors promote dispersed ownership ${ }^{40}$ but disregards the fact that these blockholders are the emergent blockholder in the American capital markets. This type of oversight may have also found its way into regulatory circles.

Another imbalance in the regulatory treatment of institutional investors that can also be found in the shareholder primacy literature results from the conclusions that flow from the notion of fiduciaries as promoting diffused ownership. This imbalance stems from the idea that institutional shareholders have interests that are homogenous with other shareholders. ${ }^{41}$ Consequently, building on such an understanding, regulatory initiatives that tend to empower institutional investors may not

${ }^{36}$ Carolyn K. Brancato \& Stephan Rabimov, The 2008 Institutional Investment Report: Trends in Institutional Investor Assets and Equity Ownership of U.S. Corporations (2008). Similarly, see James Hawley \& Andrew Williams, Universal Owners: Challenges and Opportunities, 15 Corp. Gov. 415 (2007), observing (at 415), "most importantly, while there are many institutional investors, holdings are, in fact, concentrated in the hands of a relatively small number of the very largest institutional investors. For example, in the USA, the 100 largest fiduciary institutions hold fully 52 per cent of all publicly held equity” [emphasis in the original].

${ }^{37}$ See, e.g., Thomas N. Carver, The Diffusion of Ownership of Industries in the United States, 11:3 Proceedings of the Academy of Political Science in the City of New York, Popular Ownership of Property: Its Newer Forms and Social Consequences 39, 39 (1925) (noting at 46, "[t]he sixty billions ... worth of life-insurance policies owned by many millions of individuals are themselves forms of diffused ownership, even though these virtual owners do not exercise control over the industries in which their funds are invested”) ; and Robert L. Cox, Policy-Holder Ownership and Interest Through Investment of Life Insurance Funds, 11:3 Proceedings of the Academy of Political Science in the City of New York, Popular Ownership of Property: Its Newer Forms and Social Consequences 75, (1925).

${ }^{38}$ See, e.g., Stephen Davis, Mobilizing Ownership - The Civil Economy Agenda, 0.618..., Jan. 2005, at 8, available at http://www.unepfi.org/publications/0618/index.html (claiming that "[p]olicymakers around the world have a historic window of opportunity to shepherd a new policy of growth that transcends outmoded divides between at the anticapitalism of the traditional left and the laissez-faire corporatism of the traditional right. The reason is the rise of mass ownership [referring to equity ownership via institutional investors]").

${ }^{39}$ Pichhadze, supra, note 5, 68-71 and 73-79.

${ }^{40}$ Henry Hansmann \& Reinier Kraakman, The End of History for Corporate Law, in Convergence and Persistence in Corporate Governance 33, 48-49 (Jeffrey N. Gordon \& Mark J. Roe eds., 2004).

${ }^{41} I d$. 
be construed as sources of imbalance. However, such an understanding distorts the analysis once we realize that shareholders are, in fact, a heterogeneous group with very different interests (though some interests may be common to all). This realization serves to amplify the abovementioned paradox.

Thus paradox serves to highlight two important observations. First, by introducing an imbalance in favour of shareholders of large corporations and viewing institutional investors as the promoters of diffused ownership, regulators may, unintentionally, be empowering this group of investors via legislative efforts. Second, the contradictory treatment of institutional investors also serves to illustrate the point where economic analysis and legal analysis of regulation diverge from one another.

(a) Empowering institutional investors through legislation

The paradoxical treatment of institutional investors has been largely overlooked in the corporate governance literature. $^{42}$ As a result, it may also have evaded the policymaker. While the SEC has been concerned with the institutionalization of the capital markets in the US since the $1960 \mathrm{~s},{ }^{43}$ its amendments to the proxy rules (including the Proposal) may have, in fact, worked to empower institutional investors.

In the context of the proxy rules, it has been observed that since the late 1980s, institutional investors in the US, under the leadership of such actors as the California Public Employees Retirement System (CalPERS), sought to amend the these rules in order to achieve three objectives: (i) to protect the market for corporate control by removing anti-takeover measures adopted by managements and boards; (ii) to increase shareholder input into corporate decision-making; and (iii) to influence the election of corporate boards. ${ }^{44}$ According to Sargent and Honabach, institutional investors have been successful in their efforts to influence the SEC and US Congress in amending the proxy rules to facilitate the first two of these goals. The third objective is currently in the proposal stages (i.e., the Proposal).

Shareholders are a group. As such, it allows them to benefit from the cooperative actions of group members. ${ }^{45}$ Such gains, however, are balanced against the negative impact of activities such as rent-seeking and opportunism carried out by some group members at the expense of others. This is because shareholders, as a heterogeneous group, ${ }^{46}$ have their own interests in addition to the com-

\footnotetext{
${ }^{42}$ Pichhadze, supra, note 5, at 71-74.
}

${ }^{43}$ The Securities and Exchange Commission (SEC), for example, commissioned a number of studies of the mutual fund industry in the 1960s to understand the implication of the growth of the industry to the capital markets (id. at 73)

${ }^{44}$ Sargent \& Honabach, supra, note 3.

${ }^{45}$ In the context of corporate law, efforts by institutional investors during the 1990s to reduce restrictions on shareholder communications may be thought of as an example of such efforts. Yet, even this example is subject to a qualification. This is because institutional investors were arguing in support of the proposed changes that they were longterm investors whereas the evidence was to the contrary (see, e.g., Pichhadze, supra, note 5, at 81).

${ }^{46}$ See, e.g., Iman Anabtawi \& Lynn Stout, Fiduciary Duties for Activist Shareholders, 60 Stan. L. Rev., 1255 (2008) (noting, at 1258, that "even as shareholders are becoming more powerful, their interests are becoming more hetero- 
mon interests shared by all shareholders. The type of rent-seeking or opportunism relevant to our discussion in this context is what has been referred to as political rent-seeking. Here, public choice theory provides that larger groups will be "more inclined to produce pressure in the pursuit of group-specific public goods." ${ }^{47}$ An example of this can be found in the efforts of institutional investors to influence the composition of corporate boards (i.e., the third goal referred to above).

The Proposal is cushioned in language that is embracive of all shareholders in allowing them to participate in the process of nominating directors. The Proposal's threshold requirements, however, are such that only a select group of shareholders can meet these requirements. ${ }^{48}$ This select group is composed mainly of institutional investors who, as a consequence of the size of their holdings, can meet the threshold requirements. As I have noted elsewhere, ${ }^{49}$ the Proposal, by invariably strengthening the voice of financial blockholders (who are able to meet the Proposal's threshold requirements), reinforces (and supplements) the trend towards the MOBM in the American capital markets. In so doing the Proposal creates an environment that aids such investors in influencing the board of directors in a manner that is akin to non-financial blockholders and may, potentially detract from the sought after aim of protecting outside investors.

While the above may lead to the tentative conclusion that the policymaker is actually aware of the trend towards the MOBM, the fact that no additional regulatory action is taken (in terms of updating the overall regulatory framework to give recognition to the trend) works against such a conclusion. The reason is that an overhaul of the overall regulatory framework and some of its fundamental assumptions (e.g., the reliance on the Berle-Means Corporation as properly representing the typical American public firm) mandates that the regulator take positive steps to update the various areas of the regulatory framework to give regulatory recognition to the changing investor landscape. Such positive steps will also recognize that the burdens and opportunities created by the MOBM differ substantially from the burdens and opportunities created by the diffused ownership structure.

While daunting at first blush, a regulatory movement in this direction will ensure that removal of imbalances embedded in the current system and the reduction of the resulting regulatory systemic risk will lead to improved regulatory framework and the sustainment of improved and enhanced shareholder protection.

geneous”). See also, Iman Anabtawi, Some Scepticism about Increasing Shareholder Power, 53 UCLA L. Rev. 561 (2005-2006) (providing examples of shareholder and institutional shareholder heterogeneity).

${ }^{47}$ Frans van Winden, Interest Group Behavior and Influence, in Encyclopaedia of Public Choice 118, at 120 (1 Charles Kershaw Rowley, ed., 2003).

${ }^{48}$ The Proposal recommends a tiered system with various ownership thresholds (both in terms of size and duration of holding) depending on the size of the corporation in order to allow shareholders who meet the criteria to nominate a director to the corporation's board.

${ }^{49}$ Pichhadze, supra, note 5, 87-88. 
(b) Divergence between economic and legal analysis

In addition to empowering institutional shareholders via regulation, the paradoxical treatment of this group of investors also highlights the point of departure between economic analysis and legal analysis of corporate governance, both at the national and international levels.

Institutional investors are instrumental in, and for, the introduction of codes of corporate governance. They produce their own codes of best corporate governance practices, which they try encourage their portfolio firms to adopt. Institutional investors are also relied upon by governmental agencies for the adoption and introduction of codes recommended by these governmental agencies to institutional investors' portfolio firms. ${ }^{50}$ Thus, corporate governance regulation can be seen as "transnational and hybrid in nature." 51

This reliance on institutional investors poses a challenge to policy making. From an economic analysis perspective, whether we view them as blockholders or agents for the diffusion of ownership, institutional investors, as a powerful financial actor in the capital markets, offer the potential vehicle for the improvement of corporate governance practices. That is, institutional investors, as blockholders and transnational agents, possess the power and means for the introduction of the requisite change at both the national and international levels. Yet, this change poses a potential conflict due to the legal treatment accorded to institutional investors.

The conflict may be due to the source of the proposed governance change or initiative. If the proposed change/initiative originates with the institutional investor, it does not automatically translate to mean that this proposed change is for the benefit of all the shareholders of the corporation, as their interests are not necessarily identical to those of other shareholders. If, on the other hand, the change/initiative originates from the State, the State may need to rely on the institutional investor to enforce compliance by portfolio firms with the proposed change. When the State does this, it does so based on the notion that the institutional investor is a powerful and influential blockholder in the markets.

While there may not be conflict per se in this process, it does lead us to question the fundamentals of corporate laws in countries such as the US, where the notion of dispersed ownership as being characteristic of the ownership pattern in that country is still upheld. This, therefore, leads to the conclusion that, by necessity, the regulatory framework in the US needs to be updated in order to give regulatory recognition to the fact that the ownership pattern in the US is the MOBM and that the blockholder in these markets is the institutional investor.

We can take this a little further. By failing to recognize that the MOBM represents the appropriate ownership pattern in the US and by continuing to promote policy initiatives that are premised on the assumption that the ownership pattern in the US is diffused, as in the proxy rules example, it is feasible that policymakers are introducing a distortion into the regulatory system. This is because

\footnotetext{
${ }^{50}$ See, e.g., Chris A. Mallin, Corporate Governance (2007), at 82-85.

51 Peer Zumbansen, Transnational Legal Pluralism (CLPE Research Paper No. 01/2010, 2010) 21, available at http://ssrn.com/abstract=1542907.
} 
the two ownership patterns (i.e., diffused, on the one hand, and MOBM, on the other) give rise to different results and, as such, require different regulatory treatment. Such a distortion can lead to regulatory systemic risk.

\section{CONCLUSION}

The task of meeting the challenges posed by the economic realities introduced by the recent economic crisis is a demanding one. On the one hand, policymakers are required to ensure that systemic risk is reduced or eliminated from the capital markets so as to avoid the possibility of a recurring crisis. On the other hand, policymakers must be cognisant of the fact that, in the process of meeting short-term demands, they might introduce long-term imbalances into the system.

These challenges are magnified in cases where policymakers are unaware of distortions introduced into the regulatory framework through regulation founded on a distortion, as in the case of the proxy rules in the US. Here, distortions introduced into legislation in the 1930s (e.g., the idea that the Berle-Means Corporation is representative of the typical American public firm) remain part of the legislative framework despite the fact that the foundation of the regulatory scheme can no longer be said to be accurate due to the rise to prominence of institutional investors and the fact that the ownership patter in the US is more appropriately understood under the MOBM.

The significance of these observations is further amplified when we consider the extent to which ownership patterns affect various aspects of corporate and securities laws. Accordingly, in addition to current reform initiatives undertaken by regulators in response to the recent economic crisis, it is urged that regulators address the various imbalances that are embedded in the regulatory framework as a result of failing to realize the trend towards the MOBM for the purpose of reducing the possibility of regulatory systemic risk and, as a result, achieve improved market efficiency and increased investor protection. 